\title{
Oral bacteria in biofilms exhibit slow reactivation from nutrient deprivation
}

\author{
Correspondence \\ Luis Chávez de Paz \\ luis.chavez.de.paz@od.mah.se
}

Received 10 January 2008

Revised 25 March 2008

Accepted 27 March 2008

\author{
Luis E. Chávez de Paz, ${ }^{1}$ lan R. Hamilton ${ }^{2}$ and Gunnel Svensäter ${ }^{1}$ \\ ${ }^{1}$ Department of Oral Biology, Faculty of Odontology, Malmö University, Malmö 20506, Sweden \\ ${ }^{2}$ Department of Oral Biology, Faculty of Dentistry, University of Manitoba, Winnipeg, MB, Canada
}

\begin{abstract}
The ability of oral bacteria to enter a non-growing state is believed to be an important mechanism for survival in the starved micro-environments of the oral cavity. In this study, we examined the reactivation of nutrient-deprived cells of two oral bacteria in biofilms, Streptococcus anginosus and Lactobacillus salivarius. Non-growing cells were generated by incubation in $10 \mathrm{mM}$ potassium phosphate buffer for $24 \mathrm{~h}$ and the results were compared to those of planktonic cultures. When both types of cells were shifted from a rich, peptone-yeast extract-glucose (PYG) medium to buffer for $24 \mathrm{~h}$, dehydrogenase and esterase activity measured by the fluorescent dyes 5-cyano-2,3ditolyl-tetrazolium chloride (CTC) and fluorescein diacetate (FDA), respectively, was absent in both species. However, the membranes of the vast majority of nutrient-deprived cells remained intact as assessed by LIVE/DEAD staining. Metabolic reactivation of the nutrient-deprived biofilm cells was not observed for at least $48 \mathrm{~h}$ following addition of fresh PYG medium, whereas the nongrowing planktonic cultures of the same two strains were in rapid growth in less than 2 h. At 72 h, the S. anginosus biofilm cells had recovered $78 \%$ of the dehydrogenase activity and $61 \%$ of the esterase activity and the biomass $\mathrm{mm}^{-2}$ had increased by $30-35 \%$. With L. salivarius at $72 \mathrm{~h}$, the biofilms had recovered $56 \%$ and $75 \%$ of dehydrogenase and esterase activity, respectively. Reactivation of both species in biofilms was enhanced by removal of glucose from PYG, and $S$. anginosus cells were particularly responsive to yeast extract (YE) medium. The data suggest that the low reactivity of non-growing biofilm cells to the introduction of fresh nutrients may be a survival strategy employed by micro-organisms in the oral cavity.
\end{abstract}

\section{INTRODUCTION}

Biofilms are accumulations of micro-organisms within a complex matrix that adhere to a surface; they are closely linked with the aetiology of diverse chronic and recurrent human infections (Davey \& O'Toole, 2000), device-related infections and treatment failures (Gilbert et al., 2002; HallStoodley et al., 2004). In the human mouth, there is an unrestricted formation of natural microbial biofilms on the various tooth surfaces, generally referred to as dental plaque, which are associated with the occurrence of oral diseases such as dental caries, different forms of periodontal disease and root canal infections (Bowden, 1991; Chávez de Paz, 2007; Marsh, 2005; Sansone et al., 1993; Socransky \& Haffajee, 2002).

The rate of growth of dental plaque on tooth surfaces is dependent on ecological determinants such as the available nutrients, the competing organisms in the community and

Abbreviations: CSLM, confocal scanning laser microscopy; CTC, 5cyano-2,3-ditolyl tetrazolium chloride; EB, ethidium bromide; FDA, fluorescein diacetate; PBS, $10 \mathrm{mM}$ potassium phosphate buffer; PY; peptone-yeast extract; PYG, peptone-yeast extract-glucose; YE, yeast extract. the environmental conditions in the biofilm at the time. Compared to many ecosystems, the nutrient supply available to bacteria in the oral cavity is more abundant and localized at times when the host consumes food (feast), although the period of time over which this occurs is much shorter than when no added nutrients are consumed (famine) (Carlsson \& Johansson, 1973; De Jong \& Van der Hoeven, 1987; Van der Hoeven \& Camp, 1991). In other micro-environments of the oral cavity, such as root canals of teeth, nutrients are commonly scarce and the colonizing micro-organisms frequently need to survive under nutrient deprivation. Bacteria under the stress of starvation have developed efficient adaptive regulatory reactions to shift their metabolic balance away from biosynthesis and reproduction, toward the acquisition of energy for existing biological functions (Giard et al., 1997; Kim et al., 2001; Matin, 1990; Watson et al., 1998). Cultures of Escherichia coli, Streptococcus equisimilis, Bacillus subtilis and Streptococcus pyogenes that are deprived of amino acids, carbon, glucose or iron induce a stringent response dependent on the synthesis of guanosine nucleotides [(p)ppGpp], which favour activities that facilitate adaptation to the nutritional stress (Chatterji \& Ojha, 2001; 
Mechold \& Malke, 1997; Miethke et al., 2006; Steiner \& Malke, 2000). Despite considerable speculation, information is scarce concerning starvation responses among oral bacteria, or whether such responses are stimulated in the oral environment (Bowden \& Li, 1997; Bowden \& Hamilton, 1998).

From the physiological perspective, nutrient deprivation causes bacteria to reversibly switch to a state of metabolic arrest (Amy \& Morita, 1983; Stevenson, 1977). At these very low metabolic rates, bacteria will survive a wide range of environmental threats, in addition to deprivation of nutrients, such as temperature shifts and extreme $\mathrm{pH}$ changes, as well as exhibiting decreased sensitivity to antimicrobial agents (Oliver, 1995). When the nutrient supply is favourable again, the stress response is released and the bacteria resume metabolic activity and cell division. A large amount of RNA and protein appears to be degraded rapidly at the onset of starvation (Jenkins et al., 1988), which is believed to be part of a general stress response (GSR) that is connected to survival responses in changing environments like the oral cavity (Brown \& Smith, 2001; Foley et al., 1999).

Low metabolism of bacteria in biofilms has also been suggested for survival of oral bacteria. In a mixed continuous culture of Streptococcus mutans and Lactobacillus casei receiving high levels of fluoride $(20 \mathrm{mM})$, the growth of $S$. mutans was inhibited below the level of detection and yet the organism survived for 5 days in the presence of fluoride, presumably in a biofilm on the surfaces of the chemostat (Bowden \& Hamilton, 1989). In the present study, we investigated two clinical isolates from the human mouth, Streptococcus anginosus, a predominant streptococcus in subgingival plaque (Frandsen et al., 1991), and Lactobacillus salivarius, a common commensal organism in dental plaque (Chávez de Paz et al., 2004). Both species are persistent survivors in infected root canals of teeth even after several treatment sessions (Chávez de Paz et al., 2004, 2005). The aim was to examine reactivation from non-growing cells in biofilm and planktonic cultures. For this, non-growing cultures of $L$. salivarius and $S$. anginosus were generated by nutrient deprivation in buffer and then provided with fresh nutrients in order to assess growth and metabolic reactivation. Membrane integrity and metabolic fluorescent staining analyses revealed significant differences in the physiological response of the biofilm and planktonic cultures of the same organism.

\section{METHODS}

Bacterial strains and growth conditions. Streptococcus anginosus was isolated from infected root canals of teeth (Chávez de Paz et al., 2003) and identified using the primary tests and criteria described in a previous study (Chávez de Paz et al., 2005). This strain was negative for $\beta$-N-acetylglucosaminidase, negative for $\alpha$-arabinosidase, positive for $\beta$-glucosidase, negative for acid production from inulin and positive to arginine hydrolysis. Lactobacillus salivarius was isolated from supra-gingival dental plaque (Chávez de Paz et al., 2004) and identified to species level as described in a previous study (Chávez de Paz et al., 2004). Briefly, the strain was selectively grown in Rogosa medium, tested for the fermentation of rhamnose and its metabolic products were analysed by gas-liquid chromatography. SDS-PAGE patterns of whole-cell proteins were matched with those of type strains used as positive controls. Strains were stored at $-70{ }^{\circ} \mathrm{C}$ using skim milk powder (Oxoid) diluted in double distilled water. Strains were recovered on blood agar in an atmosphere of $5 \% \mathrm{CO}_{2}$ in hydrogen at $37{ }^{\circ} \mathrm{C}$ for $24 \mathrm{~h}$.

To prepare the inoculum, colonies were transferred into liquid growth medium peptone-yeast extract-glucose (PYG) (Holdeman et al., 1977), supplemented with $10 \mathrm{mM}$ potassium phosphate buffer (PBS), $\mathrm{pH} 7.5$, and incubated in an atmosphere of $5 \% \mathrm{CO}_{2}$ in hydrogen at $37^{\circ} \mathrm{C}$ overnight. Aliquots $(500 \mu \mathrm{l})$ were transferred to $10 \mathrm{ml}$ fresh PYG (pH 7.5) and incubated at $37^{\circ} \mathrm{C}$; the $\mathrm{OD}_{600}$ was monitored until late exponential growth was reached. Normal $\mathrm{OD}_{600}$ values at late exponential phase were $0.8 \pm 0.1$ for $S$. anginosus and $0.5 \pm 0.1$ for $L$. salivarius. Cells were harvested by centrifugation $(3000$ $\mathrm{g}, 5 \mathrm{~min}$ at $4{ }^{\circ} \mathrm{C}$ ), washed in $10 \mathrm{mM}$ PBS and resuspended in PYG to a cell concentration of $1 \times 10^{8} \mathrm{ml}^{-1}$.

Biofilm formation. The flow-chamber system $\mu$-Slide VI for Live Cell Analysis (Integrated BioDiagnostics) (Fig. 1a), with working volumes of $150 \mu \mathrm{l}$, was used to create the biofilms used in the study. Each flowchamber was inoculated with $30 \mu \mathrm{l}$ of a washed suspension of cells grown to the late exponential phase in PYG, followed by addition of $100 \mu \mathrm{l}$ of fresh PYG to give a final volume of $130 \mu \mathrm{l}$ per flowchamber. Flow chambers were incubated in an atmosphere of $5 \%$ $\mathrm{CO}_{2}$ in hydrogen at $37^{\circ} \mathrm{C}$ and biofilm formation was monitored every hour by direct microscopic observation. After $24 \mathrm{~h}$ of biofilm growth, chambers were rinsed with PBS to remove non-adherent cells.

LIVE/DEAD, CTC and FDA/EB staining. Cell samples were stained separately for membrane integrity, dehydrogenase activity and esterase activity with fluorescent dyes. Hence, three triplicate sets of biofilms and planktonic samples were cultured under the same conditions, each set having its own unique total cell count. The LIVE/ DEAD BacLight Bacterial Viability kit for microscopy (product no. L7007, Molecular Probes), was used. The LIVE/DEAD mixture was prepared by mixing components A $+\mathrm{B}$ in the kit, consisting of SYTO9 and propidium iodide, at a ratio of $1: 100$ with the inoculum medium (PYG or PBS). For planktonic cultures, $10 \mu \mathrm{l}$ aliquots of the harvested-washed cells were incubated with $10 \mu \mathrm{l}$ LIVE/DEAD mixture in the dark for $15 \mathrm{~min}$ at room temperature $\left(25^{\circ} \mathrm{C}\right)$. For biofilms, $30 \mu \mathrm{l}$ of the LIVE/DEAD mixture was added after removing the culture fluid from the flow-chamber and washing with PBS. Chambers were incubated at room temperature for $15 \mathrm{~min}$. The fluorescence from stained cells was viewed using confocal scanning laser microscopy (CSLM) (see below).

The redox fluorescence dye, 5-cyano-2,3-ditolyl tetrazolium chloride (CTC) (Molecular Probes), which targets dehydrogenase activity, was used to assess the physiological status of the test bacteria. For planktonic cultures, $30 \mu \mathrm{l}$ harvested bacterial culture was mixed with $3 \mu \mathrm{l} \mathrm{CTC}(50 \mathrm{mM})$ to obtain a final CTC concentration of $5 \mathrm{mM}$. CTC mixed cultures were left in the dark at room temperature for $50 \mathrm{~min}$. For the biofilms, $30 \mu \mathrm{l} \mathrm{CTC}(5 \mathrm{mM})$ was added to the chamber after removing the culture fluid and washing with PBS, and incubated in the conditions described above. Fluorescence of the stained cells was examined by CSLM. Preliminary experiments with planktonic cultures showed that for $S$. anginosus at mid-exponential phase, $90 \% \pm 3 \%$ of the population was CTC active; while for $L$. salivarius $78 \% \pm 5 \%$ of the population was CTC active. Preliminary data have also shown that CTC staining yielded similar results in aerobic and anaerobic conditions. 
(a)

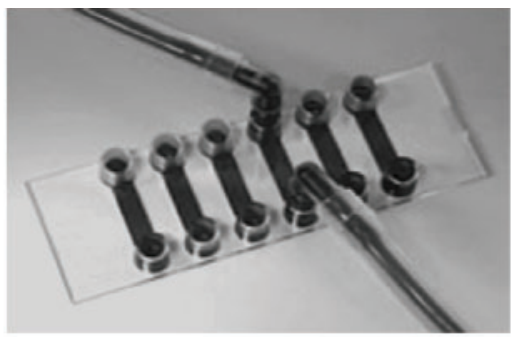

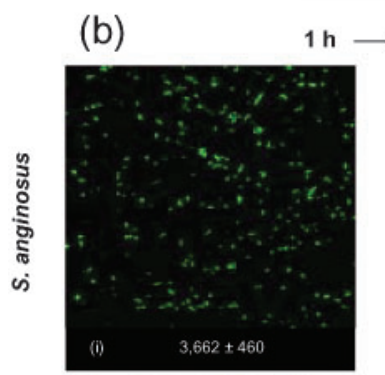

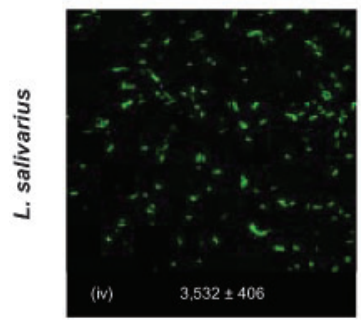

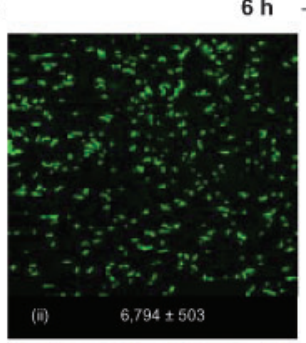

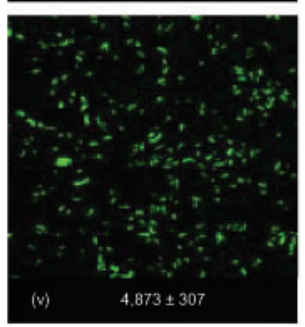

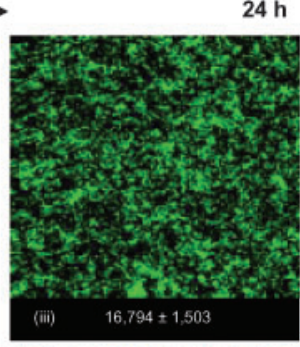

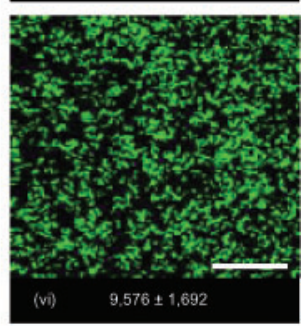

Fig. 1. (a) Flow-chamber system used for formation of biofilms. (b) Biofilm growth at 1, 6 and $24 \mathrm{~h}$ for $S$. anginosus (i-iii) and $L$. salivarius (iv-vi), using the BacLight LIVE/ DEAD technique. The values below each image are the mean total cell counts for 10 images covering a total area of $0.5 \mathrm{~mm}^{2}$ (means \pm SEM of triplicate experiments). Bar, $50 \mu \mathrm{m}$.
Fluorescein diacetate (FDA), which reacts with non-specific esterases in metabolically active micro-organisms, was used as an alternative metabolic marker in biofilm cultures. A stock solution of FDA was prepared by mixing $5 \mathrm{mg}$ FDA (Molecular Probes) $\mathrm{ml}^{-1}$ in pure acetone. The working solution was prepared by mixing $5 \mu \mathrm{FDA} /$ acetone $\mathrm{ml}^{-1}$ in the inoculum medium. After removing the culture fluid from the biofilm chamber and washing with PBS, $30 \mu \mathrm{FDA}$ working solution was added. Ethidium bromide (EB) was used as a counter-stain to visualize non-active cells. The EB stock solution was prepared by mixing $0.5 \mathrm{mg} \mathrm{EB}$ (Roth) $\mathrm{ml}^{-1} \mathrm{NaCl}$, while the working solution was a $1: 200$ dilution of this in the inoculum medium. EB was added in $20 \mu \mathrm{l}$ aliquots to the biofilm chambers already containing FDA. The biofilm chambers were incubated in the conditions described above. Fluorescence of the stained cells was examined by CSLM.

CSLM and total cell counts. All microscopy work was performed using an Eclipse TE2000 inverted confocal scanning laser microscope (Nikon). Ten randomly selected areas of each sample were imaged using a $\times 60$ magnification oil immersion objective with a numerical aperture of 1.4, and the confocal pinhole set to a diameter of $30 \mu \mathrm{m}$. For the LIVE/DEAD and FDA/EB techniques, confocal illumination was provided by an Ar laser (488 nm laser excitation) fitted with a long-pass 515/30 filter for the green fluorescence signal (emitted by SYTO9 and FDA), and a long-pass 605/75 filter for the red fluorescence signal (propidium iodide and EB). Simultaneous dualchannel imaging was used to display green and red fluorescence. For detection of the red fluorescence by CTC staining, a G-HeNe laser was used (543 nm laser excitation), together with a long-pass 605/75 emission filter. A transmission emission channel using the same laser excitation was obtained from the same microscopic field. Simultaneous imaging was used to display red CTC fluorescence and the transmission emission channel, in order to determine the numbers of cells not reacting with the CTC stain.
In all cases, CSLM images were acquired by the software EZ-C1 v.3.40 build 691 (Nikon) at a resolution of $512 \times 512$ pixels and with a zoom factor of 1.0, giving a final resolution of $0.41 \mu \mathrm{m}$ per pixel. Individual biofilm images covered an area of $0.05 \mathrm{~mm}^{2}$ per field of view. Total cell counting was performed by the analysis software Cell C (Tampere University of Technology) which separated clusters of bacteria by erosion-dilation algorithms and gave results in binarized black and white images in Excel-ready CSV files. Individual cells were enumerated and their lengths, widths and areas calculated.

Image analyses. Confocal LIVE/DEAD and FDA/EB images were analysed by using a colour segmentation algorithm written in MATLAB 7.0 for Windows (MathWorks) which, by colour thresholding, separated the red and green fluorescence signals and measured the total areas (pixels ${ }^{2}$ ) covered by each segmented colour. To calculate the number of cells per segmented colour, colour areas were divided by the mean cell area, which was calculated from the total cell counts described above; the mean cell area of $L$. salivarius was $12 \mu \mathrm{m}^{2}=76$ pixels $^{2}$; the mean cell area of $S$. anginosus was $1.1 \mu \mathrm{m}^{2}=7$ pixels ${ }^{2}$.

The numbers of cells that reacted to CTC were calculated by separating the confocal images in two, one with the transmission emission channel, which registered the total cell numbers, and the other with the red fluorescence from CTC-stained cells. The image analysis software program NIS-Elements BR v.2.30 (Nikon) was used for the channel segmentation. Each image was analysed separately with the software CELL C, and the proportion of cells stained red by CTC based on the total cell count was calculated.

Nutrient deprivation and reactivation of biofilms. Once the biofilms had been established for $24 \mathrm{~h}$, the PYG was removed and the chamber was washed with PBS; $130 \mu 10 \mathrm{mM}$ PBS (pH 7.5) was added and the mini-flow chambers were incubated in an atmosphere 
of $5 \% \mathrm{CO}_{2}$ in hydrogen at $37{ }^{\circ} \mathrm{C}$. Slides were removed at $24 \mathrm{~h}$ and subjected to LIVE/DEAD and CTC staining and analysis. After the $24 \mathrm{~h}$ buffer incubation period, unstained mini flow-chambers were washed with PBS and inoculated with PYG $(130 \mu \mathrm{l})$. Other media used to test reactivation of biofilm cells were prepared using the salt mixtures and water volumes in PYG: PYG devoid of glucose (PY), yeast extract (Difco) $10 \mathrm{mg} \mathrm{ml}^{-1}$ (YE), Trypticase Peptone (BBL) $5 \mathrm{mg} \mathrm{ml}^{-1}$ (peptone mix 1), Bacto Peptone (Difco) $5 \mathrm{mg} \mathrm{ml}^{-1}$ (peptone mix 2), and $6 \mathrm{mM}$ glucose. Additionally, the semi-defined medium (MADM) described by Bowden (1999), was used with and without glucose. The flow cells were then incubated in an atmosphere of $5 \% \mathrm{CO}_{2}$ in hydrogen at $37{ }^{\circ} \mathrm{C}$. Preliminary experiments indicated that reactivation of biofilms cells was more delayed compared to planktonic cells. Accordingly, the reactivation of biofilm cells was analysed with individual slides removed at 2, 4, 6, 24, 48, 72 and $96 \mathrm{~h}$ and subjected to LIVE/DEAD, CTC and FDA/EB staining and microscopic analysis as described above.

Nutrient deprivation and reactivation of planktonic cells. Cells were harvested in the late exponential phase of growth (described above), resuspended in $10 \mathrm{ml} 10 \mathrm{mM}$ PBS ( $\mathrm{pH} 7.5$ ) and incubated in an atmosphere of $5 \% \mathrm{CO}_{2}$ in hydrogen at $37{ }^{\circ} \mathrm{C}$. Samples were taken at $24 \mathrm{~h}$ to determine the $\mathrm{OD}_{600}$, the number of cells that were stained fluorescent-green according to LIVE/DEAD, and the percentage of cells reacting to CTC. For reactivation, cells were collected by centrifugation (3000 $\mathrm{g}$ for $5 \mathrm{~min}$ ), washed with PBS and resuspended in $10 \mathrm{ml}$ fresh PYG. Cultures were incubated in an atmosphere of $5 \%$ $\mathrm{CO}_{2}$ in hydrogen at $37{ }^{\circ} \mathrm{C}$. Since preliminary results had demonstrated that the reactivation of planktonic cells occurred within short time periods, samples were retrieved at 2, 4 and $6 \mathrm{~h}$ to check the cell parameters outlined above.

Statistical analysis. Each experiment was performed in triplicate to confirm that the patterns observed were reproducible. Two-way analysis of variance (ANOVA) was used to detect any significant variation in terms of time, variations among the three different biofilm or planktonic populations, interaction between time and bacterial populations, and random variation (error). The software package SPSS v.14 was used. The standard errors for the cell counts at each time point were calculated.

\section{RESULTS}

\section{Reproducibility of results}

The statistical analysis by the two-way ANOVA was used to determine whether there was any significant source of variation in the data resulting from the image analyses of the biofilm and planktonic populations. For most variables tested (see Methods), the two main sources of variation $(P<0.001)$ were time and random variation (error). No significant variations were observed between the three independent observations in terms of the cell counts resulting from the analyses of membrane integrity with the LIVE/DEAD technique and the reaction of cells to the CTC and FDA metabolic markers at each time point. The data reported are based on the mean of the three experimental cell counts each containing the total results of 10 images (biofilm area is $0.5 \mathrm{~mm}^{2}$ ).

\section{Biofilm growth}

Following inoculation of late-exponential phase cells to the flow chambers, growth in biofilms was monitored by direct microscopic observation and total cells counts. Fig. 1(b) shows LIVE/DEAD confocal images which demonstrate biofilm growth of S. anginosus (i-iii) and L. salivarius (ivvi), at 1, 6 and $24 \mathrm{~h}$ (see also Fig. 2a and Fig. 5a). Normally, the biofilms formed at $24 \mathrm{~h}$ were mono-layered. There were significant differences between the cell counts on the biofilms at differing time points, with the exception of one time point with $L$. salivarius. Biofilms of $S$. anginosus after $1 \mathrm{~h}$ of incubation had a total of $3662 \pm 460$ cells in an area of $0.5 \mathrm{~mm}^{2}$, while at $6 \mathrm{~h}$ the number of cells had increased twofold to $6794 \pm 503$ cells, and fivefold at $24 \mathrm{~h}$ to a total of $16658 \pm 1543$ cells. Biofilms of L. salivarius at $1 \mathrm{~h}$ of incubation had $3532 \pm 406$ cells, and despite a non- (a)

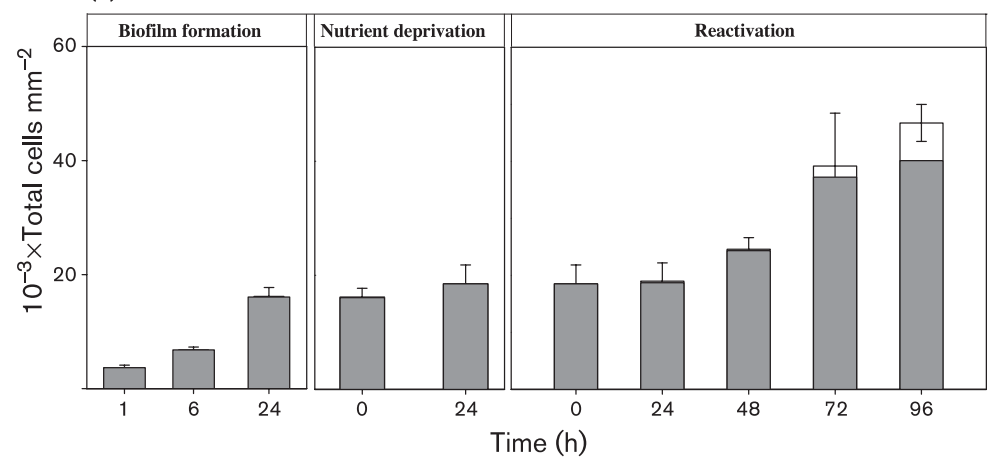

(b)

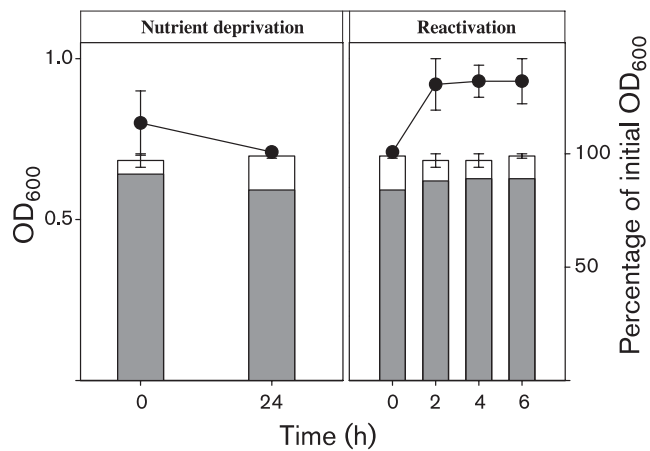

Fig. 2. Effect of $24 \mathrm{~h}$ nutrient deprivation in buffer and subsequent reactivation in fresh PYG medium on the membrane integrity of $S$. anginosus in (a) biofilms and (b) planktonic cultures as assessed by (LIVE/DEAD) fluorescent staining. In (a), dark grey bars represent green, undamaged cells; white bars denote membrane-damaged cells. Total biofilm cell counts (per $\mathrm{mm}^{2}$ ) were calculated from a total area of $0.5 \mathrm{~mm}^{2}$. In (b), grey bars represent the percentage of green, undamaged cells stained by LIVE/ DEAD analysis and white bars indicate the percentage of membrane-damaged cells. $\bullet$, Cell growth $\left(\mathrm{OD}_{600}\right)$. All values are means \pm SEM of triplicate experiments. 
significant increase to $4873 \pm 307$ cells at $6 \mathrm{~h}$, a significant threefold increase in growth to $9576 \pm 1692$ cells was registered at $24 \mathrm{~h}$.

\section{Nutrient deprivation and reactivation of S. anginosus}

To ascertain whether oral bacteria enter a state of metabolic arrest as a survival mechanism for conditions of nutrient limitation in the mouth, we carried out experiments to mimic 'famine' and 'feast' conditions. This was done by creating nutrient deprivation in buffer, followed by the introduction of fresh PYG medium, with membrane integrity and metabolic activity of biofilms of the individual bacteria assessed throughout these conditions. A further objective was to compare the response of planktonic cultures of the same organisms under the same conditions. The hypothesis was that a delay in reactivation of the cells under either condition would constitute evidence for a slow physiological response.

Fig. 2 shows the effect of $24 \mathrm{~h}$ of incubation in buffer and subsequent reactivation with fresh PYG medium on the membrane integrity of $S$. anginosus, employing the LIVE/ DEAD technique with biofilms (Fig. 2a) and planktonic cultures (Fig. 2b). Clearly, green cells, indicating undamaged cell membranes, dominated the populations of both culture types throughout the nutrient deprivation period and subsequent reactivation with fresh medium. As seen in Fig. 2(a), there were $16658 \pm 1543$ biofilm cells in $0.5 \mathrm{~mm}^{2}$ at the onset of nutrient deprivation, 99\% (16059/16 119) of which stained green (undamaged), and after $24 \mathrm{~h}$ of nutrient deprivation almost $100 \%$ of the cells (18 451/ 18488 ) were still undamaged. The addition of fresh medium did not alter the proportion of cells with sound membranes at $24 \mathrm{~h}$, with $99 \%(18695 / 18977)$ and $98 \%$
(24332/24569) at $48 \mathrm{~h}$. At $72 \mathrm{~h}$, a $37 \%$ increase in the total cells $(39168 \pm 9276)$ was observed, which was associated with a slight decrease $(5 \%)$ in percentage of intact cells, while $86 \%(40118 / 46716)$ of the cells were undamaged at $96 \mathrm{~h}$.

The results of the LIVE/DEAD staining for planktonic cells of $S$. anginosus (Fig. 2b) indicated that during incubation in buffer and reactivation, the majority of cells that were counted had intact membranes, although some red damaged cells were evident at each time point. At the onset of nutrient deprivation, $91 \%$ of the initial population of cells (34247 \pm 1861$)$ was undamaged (green), while after $24 \mathrm{~h}$ of incubation in buffer, the membrane integrity dropped to $84 \%$. Two hours after the addition of fresh medium, the $\mathrm{OD}_{600}$ of the total cell population had increased from $0.71 \pm 0.01$ to $0.92 \pm 0.08$, which was accompanied by an increase in the proportion of green cells to $88 \%$. The $\mathrm{OD}_{600}$ of the total cell population was maintained at 0.93 at $4 \mathrm{~h}$ and $6 \mathrm{~h}$ of reactivation; similarly, the percentage of cells with intact membranes was maintained at $89 \%$ at $4 \mathrm{~h}$ and $6 \mathrm{~h}$ following reactivation.

\section{Metabolic activity of S. anginosus}

The redox fluorescence dyes CTC and FDA, which target dehydrogenase activity and esterase activity, respectively, were used to assess the metabolic activity of $S$. anginosus after $24 \mathrm{~h}$ incubation in buffer and subsequent reactivation in fresh PYG medium. The proportions of cells which were able to reduce CTC and produce a red fluorescence signal indicating dehydrogenase activity in biofilms and planktonic cultures are shown in Figs 3(a) and (b), respectively. As seen in Fig. 3(a), biofilms had $14777 \pm 2456$ cells at the onset of nutrient deprivation, $65 \%(9624 \pm 1852)$ of which showed red fluorescence indicating CTC reduction. (a)

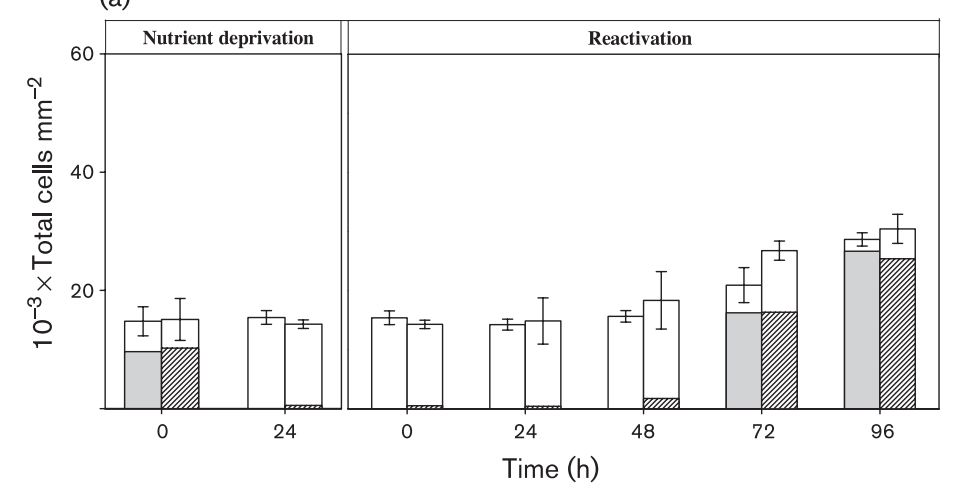

(b)

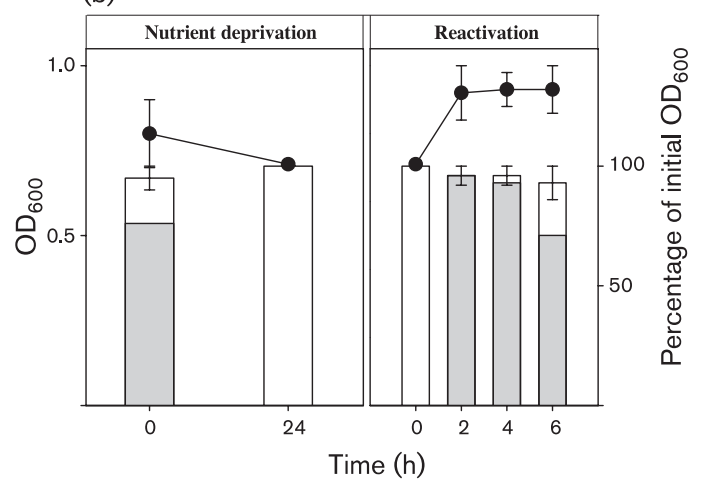

Fig. 3. Effect of $24 \mathrm{~h}$ nutrient deprivation in buffer and subsequent reactivation in fresh PYG medium on the metabolic activity of $S$. anginosus in (a) biofilms and (b) planktonic cultures. In (a), grey bars represent red, dehydrogenase-active CTC-reducing cells, hatched bars represent enzyme active FDA-reactive cells and white bars indicate the number of inactive cells. Total biofilm cell counts (per $\mathrm{mm}^{2}$ ) were calculated from a total area of $0.5 \mathrm{~mm}^{2}$. In (b), grey bars represent the percentage of the population stained red by CTC and white bars indicate the percentage of inactive cells. $\bullet$, Cell growth $\left(\mathrm{OD}_{600}\right)$. All values are means $\pm \mathrm{SEM}$ of triplicate experiments. 
However, after $24 \mathrm{~h}$ of nutrient deprivation, none of the $15406 \pm 1158$ total cells showed metabolic activity (see representative image in Fig. 4a). As seen in Fig. 3(a) and Fig. 4, no CTC-reactive red cells were present at 2, 24 and $48 \mathrm{~h}$ following the addition of fresh nutrients, indicating no detectable dehydrogenase activity in cells. However, dehydrogenase reactivation increased with time: there were $78 \%$ active red cells at $72 \mathrm{~h}(16232 / 20928$ cells) (Fig. $4 \mathrm{e}$ ) and $93 \%$ at $96 \mathrm{~h}(26665 / 28658$ cells $)$.

The proportion of cells which were able to reduce FDA and produce a green fluorescent signal is also presented in Fig. 3(a). At the onset of nutrient deprivation, $68 \%$ (10 242/ $15086)$ of cells reacted to FDA, i.e. showed esterase activity; however, after $24 \mathrm{~h}$ of nutrient deprivation, less than $1 \%$ of the $14281 \pm 720$ total cells showed esterase activity. Following the addition of fresh nutrients, no increase in FDA-reactive green cells was observed at 2 and $24 \mathrm{~h}$. However, esterase activity was observed at $48 \mathrm{~h}$ with $10 \%(1752 \pm 545)$ green active cells; this increased to $61 \%(16344 \pm 1821$ cells $)$ at $72 \mathrm{~h}$ and $83 \%(25380 \pm 2016$ cells $)$ at $96 \mathrm{~h}$.

By way of comparison, planktonic cells also became metabolically inactive during the $24 \mathrm{~h}$ nutrient deprivation period (Fig. 3b). As seen at the onset of nutrient deprivation, $76 \%$ of the initial total cells $(15151 \pm 517)$ showed metabolic activity, while after $24 \mathrm{~h}$ nutrient deprivation, none of the cells in the total population were metabolically active (Fig. 4f). As in the LIVE/DEAD experiment (Fig. 2), the addition of fresh medium resulted in cell growth and rapid renewal of planktonic cell metabolic activity. After $2 \mathrm{~h}$, the $\mathrm{OD}_{600}$ of planktonic cells increased from 0.71 to 0.92 ; CTC staining indicated that $96 \%$ of the cells were red and active (Fig. $4 \mathrm{~g}$ ). At 4 h, $93 \%$ of the cells were active at an OD of 0.93 . The population remained constant at $6 \mathrm{~h}$; however, metabolic activity decreased to $71 \%$.

\section{Nutrient deprivation and reactivation of L. salivarius}

As with S. anginosus, LIVE/DEAD fluorescent staining tests with biofilm and planktonic cultures of $L$. salivarius revealed a high proportion of green cells, indicating undamaged cell membranes throughout the $24 \mathrm{~h}$ incubation in buffer and reactivation in fresh medium. As seen in Fig. 5(a), $99 \%$ of the biofilm cells were green from the onset of nutrient deprivation to the $48 \mathrm{~h}$ sample in the reactivation period. A slight decrease was observed $72 \mathrm{~h}$ after the addition of fresh PYG medium, where $95 \%$ of the cells $(10246 / 10828$ cells $)$ were undamaged, while the fluorescent green cell count dropped to $82 \%$ (11909/ 14451 cells) at $96 \mathrm{~h}$. Similarly, $99 \%$ of the total cells in planktonic cultures of L. salivarius (Fig. $5 \mathrm{~b}$ ) showed green fluorescence at the end of the nutrient deprivation phase and through $4 \mathrm{~h}$ of the recovery period, while membrane integrity declined to $86 \%$ at $6 \mathrm{~h}$ (Fig. 5b).

\section{Metabolic activity of $L$. salivarius}

As seen in Fig. 6(a) and Fig. 7, at the onset of nutrient deprivation, $56 \%$ (4595/8 252) of cells reduced CTC, while after $24 \mathrm{~h}$ nutrient deprivation, none of the cells in the
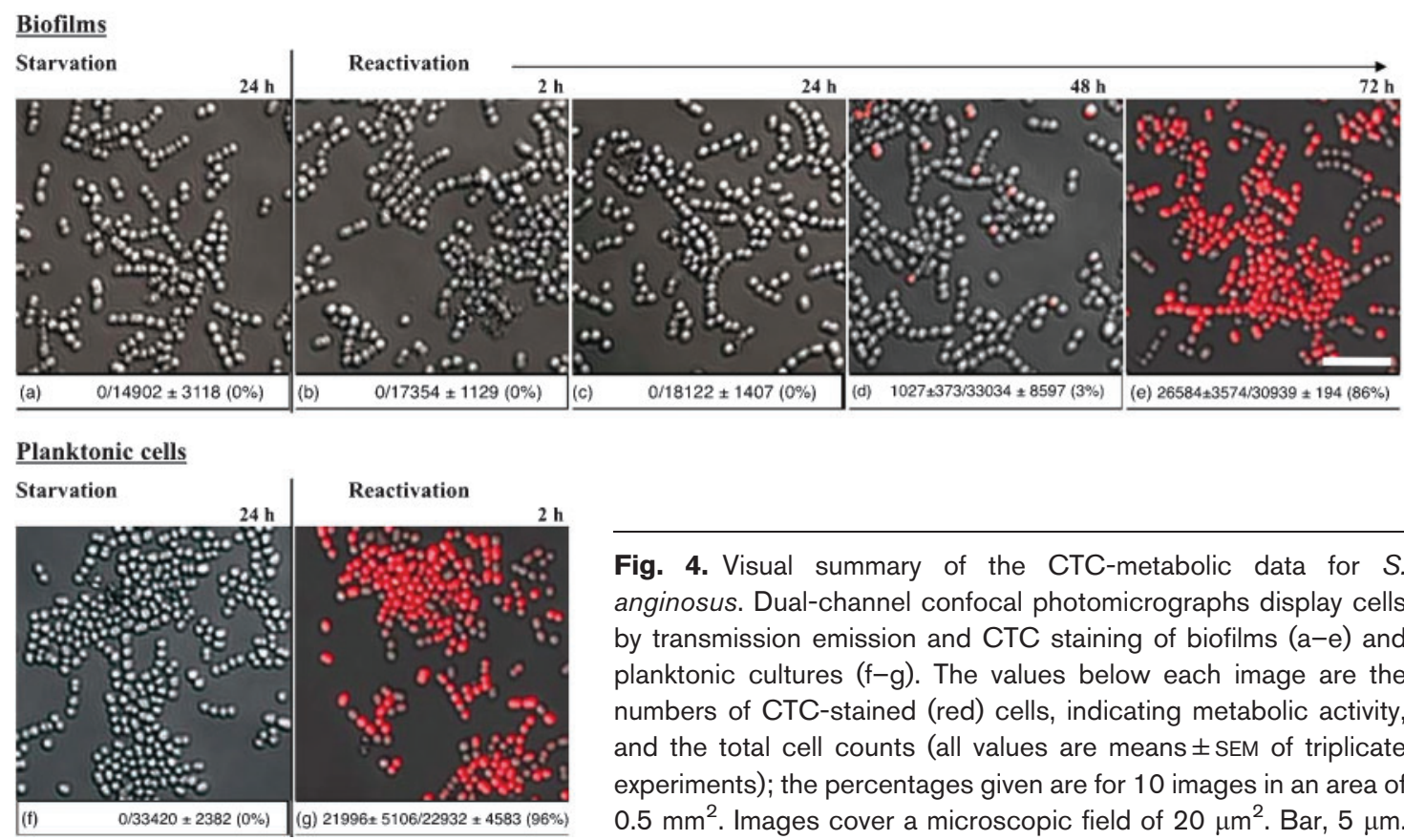

Fig. 4. Visual summary of the CTC-metabolic data for $S$. anginosus. Dual-channel confocal photomicrographs display cells by transmission emission and CTC staining of biofilms $(\mathrm{a}-\mathrm{e})$ and planktonic cultures $(f-g)$. The values below each image are the numbers of CTC-stained (red) cells, indicating metabolic activity, and the total cell counts (all values are means \pm SEM of triplicate experiments); the percentages given are for 10 images in an area of $0.5 \mathrm{~mm}^{2}$. Images cover a microscopic field of $20 \mu \mathrm{m}^{2}$. Bar, $5 \mu \mathrm{m}$. 
(a)

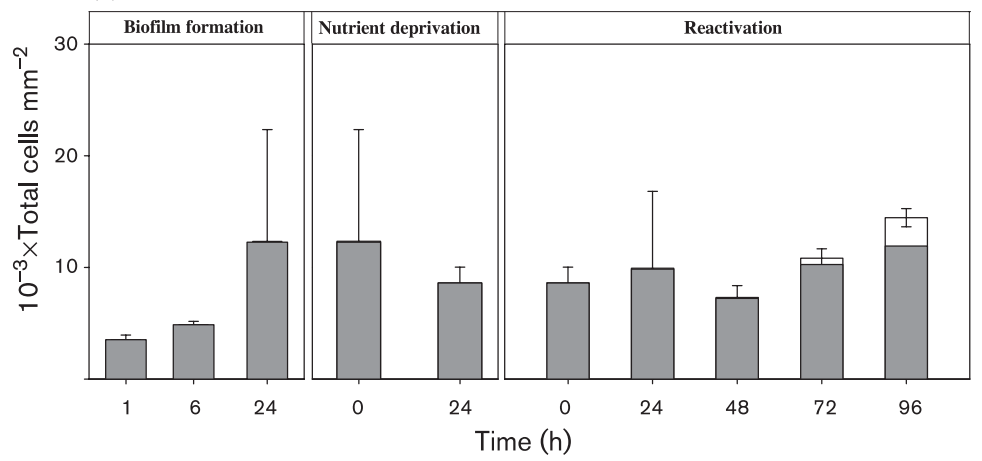

(b)

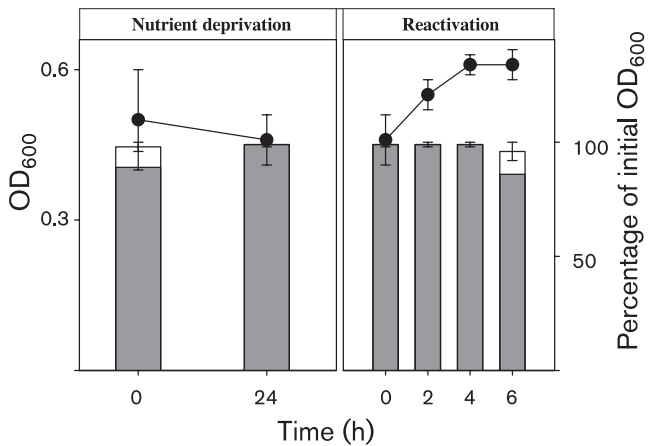

Fig. 5. Effect of $24 \mathrm{~h}$ nutrient deprivation in buffer and subsequent reactivation in fresh PYG medium on the membrane integrity of $L$. salivarius in (a) biofilms and (b) planktonic cultures as assessed by (LIVE/DEAD) fluorescent staining. In (a), dark grey bars represent green, undamaged cells, while white bars denote membrane-damaged cells. Total biofilm cell counts (per $\left.\mathrm{mm}^{2}\right)$ were calculated from a total area of $0.5 \mathrm{~mm}^{2}$. In (b), grey bars represent the percentage of green, undamaged cells stained by LIVE/ DEAD analysis and white bars indicate the percentage of membrane-damaged cells. $\bullet$, Cell growth $\left(\mathrm{OD}_{600}\right)$. All values are means \pm SEM of triplicate experiments.

total population $(9546 \pm 4080)$ showed dehydrogenase activity (Fig. 7a). Of particular interest was the fact that the addition of fresh medium to the non-growing biofilms did not result in CTC reduction (i.e. red cells) at $24 \mathrm{~h}$ and $48 \mathrm{~h}$ samples (Figs 7c and d, respectively). Reactivation started at $72 \mathrm{~h}$, when $56 \%(5056 / 9102)$ of the cells showed dehydrogenase activity (Fig. 7e); the fraction of these cells increased to $79 \%(7665 / 9654$ cells $)$ at $96 \mathrm{~h}$. Unlike in $S$. anginosus, no significant increase in the biomass $\mathrm{mm}^{-2}$ was linked to the metabolic reactivation.

Fig. 6(a) shows the proportion of cells which were able to reduce FDA and produce a green fluorescent signal. At the onset of nutrient deprivation, $42 \%$ (3501/8340) of cells reduced FDA; however, after $24 \mathrm{~h}$ nutrient deprivation, less than $1 \%$ of the total cells $(8547 \pm 1111)$ showed esterase activity. Following the addition of fresh nutrients, no increase in FDA-reactive green cells was observed at $24 \mathrm{~h}$. However, esterase activity was observed as active green cells in $15 \%(1082 \pm 253)$ of cells at $48 \mathrm{~h}$; this increased to $75 \%$ $(6595 \pm 485)$ at $72 \mathrm{~h}$, and $90 \%(7509 \pm 696$ cells $)$ at $96 \mathrm{~h}$.

As seen in Fig. 6(b), the metabolic reactivation of planktonic cultures of $L$. salivarius was much faster than that seen with corresponding biofilm cultures. At the onset of nutrient deprivation, $46 \%$ of the cells (6090/13 278) were active; however, after $24 \mathrm{~h}$ in buffer, only $3 \%$ of the cells reduced CTC (Fig. 7f). Within $2 \mathrm{~h}$ of the addition of (a)

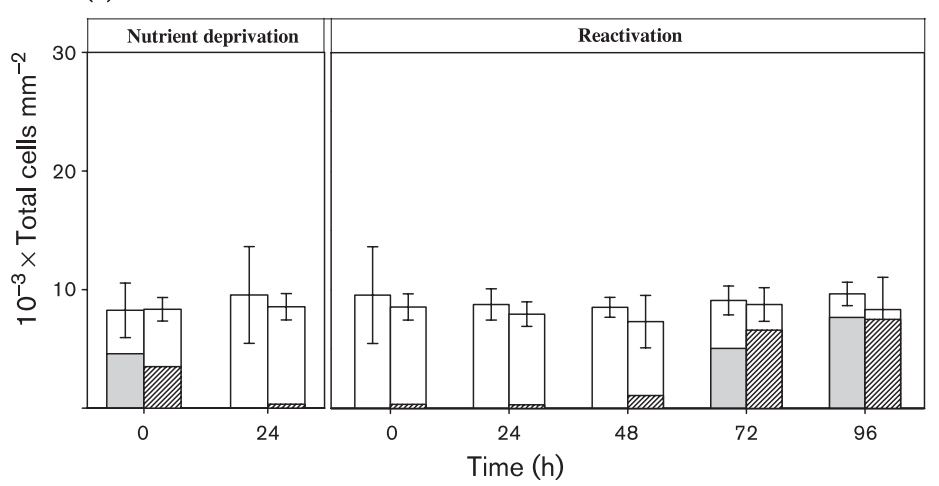

(b)

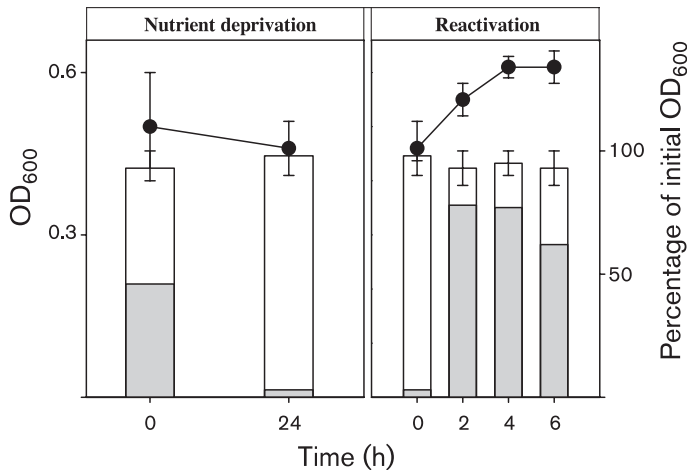

Fig. 6. Effect of $24 \mathrm{~h}$ nutrient deprivation in buffer and subsequent reactivation in fresh PYG medium on the metabolic activity of $L$. salivarius in (a) biofilms and (b) planktonic cultures. In (a), grey bars represent red, dehydrogenase active CTC-reducing cells, hatched bars represent enzyme active FDA-reactive cells and white bars indicate the number of inactive cells. Total biofilm cell counts (per $\mathrm{mm}^{2}$ ) were calculated from a total area of $0.5 \mathrm{~mm}^{2}$. In (b), grey bars represent the percentage of the population stained red by CTC and white bars indicate the percentage of inactive cells. $\bullet$, Cell growth $\left(\mathrm{OD}_{600}\right)$. All values are means $\pm \mathrm{SEM}$ of triplicate experiments. 


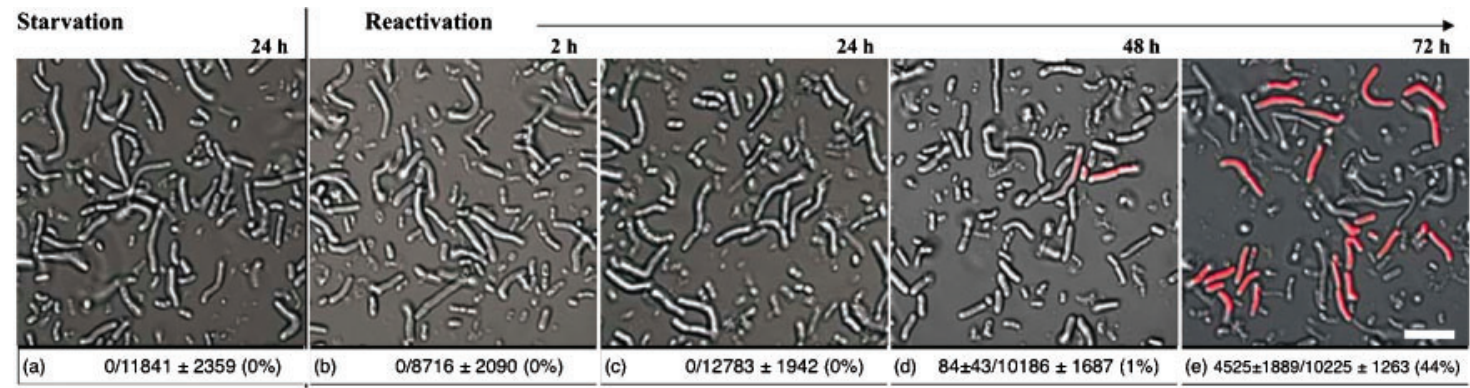

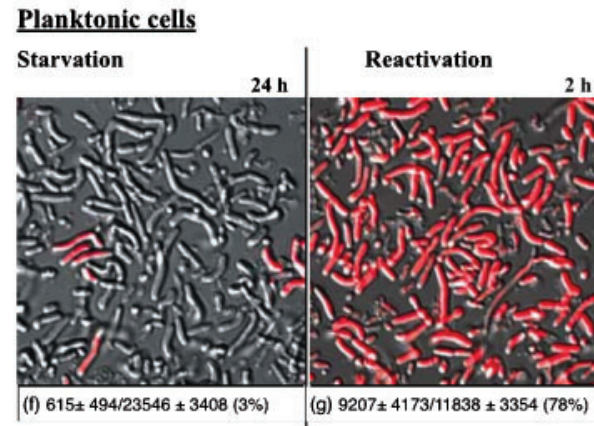

Fig. 7. Visual summary of the CTC-metabolic data for L. salivarius. Dual-channel confocal microphotographs display cells by transmission emission and CTC staining of biofilms $(\mathrm{a}-\mathrm{e})$ and planktonic cultures $(f-g)$. The values below each image are the numbers of CTC-stained (red) cells, indicating metabolic activity, and the total cell counts (all values are means \pm SEM of triplicate experiments); the percentages given are for 10 images in an area of $0.5 \mathrm{~mm}^{2}$. Images cover a microscopic field of $30 \mu \mathrm{m}^{2}$. Bar, $5 \mu \mathrm{m}$. fresh medium, there was a significant increase to $78 \%$ in the number of cells stained fluorescent red with CTC (Fig. 7g) and this metabolic activity was associated with an increase in $\mathrm{OD}_{600}$ values from $0.46 \pm 0.05$ to $0.55 \pm 0.03$, indicating cell growth. The planktonic population increased to $\mathrm{OD}_{600} 0.61 \pm 0.02$ at $4 \mathrm{~h}$, with $77 \%$ of cells registered as metabolically active. At $6 \mathrm{~h}$, the $\mathrm{OD}_{600}$ measurements did not change (0.61), however, CTC reduction dropped to $62 \%$.

\section{Effect of different medium in reactivation of biofilm cells}

Seven additional media were tested for reactivation of nutrient-deprived biofilm cells, five containing isolated components of PYG and two semi-defined: MADM and MADM without glucose. As shown in Table 1, both organisms showed dehydrogenase and esterase activity with PY and YE. Reactivation of S. anginosus in PY started at $48 \mathrm{~h}$, when $16 \%$ and $30 \%$ of cells were reactive with CTC and FDA, respectively, and an $11 \%$ increase in biomass $\mathrm{mm}^{-2}$ was seen. Reactivation of cells gradually increased, with $59 \%$ and $61 \%$ reactive cells and a $34 \%$ increase in biomass $\mathrm{mm}^{-2}$ at $72 \mathrm{~h}$, and $85 \%$ and $88 \%$ reactive cells and $46 \%$ increase in biomass $\mathrm{mm}^{-2}$ at $96 \mathrm{~h}$. As shown in Table 1, YE induced a faster reactivation of $S$. anginosus, with $4 \%$ of cells displaying esterase activity at $24 \mathrm{~h}$. At $48 \mathrm{~h}, 54 \%$ and $41 \%$ were metabolically active cells (CTC and FDA, respectively) with an increase in biomass $\mathrm{mm}^{-2}$ of $26 \%$; at 72 h, $76 \%$ and $77 \%$ cells were reactivated, with a $45 \%$ increase in biomass. For L. salivarius, PY was more effective than PYG for reactivation, since at $72 \mathrm{~h}$ reactivation, $50 \%$ and $66 \%$ of cells were active, with an increase in biomass of $36 \%$. Unlike with PYG, an increase in biomass $(20 \%)$ at $96 \mathrm{~h}$ was also seen by L. salivarius reactivated with YE. Peptone mix 1, peptone mix 2, $6 \mathrm{mM}$ glucose, MADM and MADM without glucose did not show any improvement in the reactivation of both species.

\section{DISCUSSION}

A state of metabolic arrest, often referred to as dormancy, caused by nutrient deprivation has been intensely studied in cultures of E. coli and Micrococcus luteus grown in liquid or planktonic suspensions (Jenkins et al., 1988; Kaprelyants \& Kell, 1993), but little is known about this process for oral bacteria or organisms in biofilms. In oral micro-environments such as endodontically treated root canals of teeth, it is generally assumed that persisting bacteria survive nutrient deprivation and other stresses by entering nongrowing physiological states (Chávez de Paz, 2007). In this study, we were able to distinguish non-growing states of $L$. salivarius and $S$. anginosus in biofilm cultures while incubated in fresh medium after a period of nutrient deprivation in buffer. Importantly, after $24 \mathrm{~h}$ of incubation in buffer, essentially all cells showed intact membranes (fluorescent green according to LIVE/DEAD analysis) (Figs 2a, 5a), with no measurable metabolic activity detected using the CTC and/or FDA fluorescent markers (Figs 3a, $4 a, 6 a, 7 a)$. The slow physiological reactive phenotype in biofilm cultures was recognized when fresh PYG was added to the flow chambers and the undamaged populations of $S$. anginosus (Fig. 4b-d) and L. salivarius (Fig. 7b-d) showed no significant metabolic activity at $48 \mathrm{~h}$. It was apparent that the slow physiological response of $L$. salivarius biofilm cells was longer lasting than that of S. anginosus since no increase in the biomass $\mathrm{mm}^{-2}$ was evident after the addition of fresh medium. Thus, while both organisms survived the $24 \mathrm{~h}$ nutrient deprivation period with intact 
Table 1. Percentage of $S$. anginosus and $L$. salivarius cells reactive with CTC and FDA, and the biomass increase during reactivation in $P Y G, P Y$ and $Y E$ medium

\begin{tabular}{|c|c|c|c|c|c|c|c|c|c|}
\hline \multirow[t]{2}{*}{ Time (h) } & \multicolumn{3}{|c|}{ PYG $^{*}$} & \multicolumn{3}{|c|}{$\mathrm{PY} \dagger$} & \multicolumn{3}{|c|}{ YE $\neq$} \\
\hline & CTC & FDA & $\begin{array}{c}\text { Biomass } \\
\mathrm{mm}^{-2}\end{array}$ & CTC & FDA & $\begin{array}{c}\text { Biomass } \\
\mathrm{mm}^{-2}\end{array}$ & CTC & FDA & $\begin{array}{c}\text { Biomass } \\
\mathrm{mm}^{-2}\end{array}$ \\
\hline \multicolumn{10}{|c|}{ S. anginosus } \\
\hline 0 & - & - & - & - & - & - & - & - & - \\
\hline 24 & - & - & - & - & - & - & - & $4 \pm 1$ & - \\
\hline 48 & - & $10 \pm 3$ & - & $16 \pm 2$ & $30 \pm 8$ & $11 \pm 8$ & $54 \pm 6$ & $41 \pm 4$ & $26 \pm 6$ \\
\hline 72 & $78 \pm 5$ & $61 \pm 7$ & $28 \pm 3$ & $59 \pm 4$ & $61 \pm 4$ & $34 \pm 8$ & $76 \pm 3$ & $77 \pm 4$ & $45 \pm 2$ \\
\hline 96 & $93 \pm 3$ & $83 \pm 7$ & $43 \pm 2$ & $85 \pm 2$ & $88 \pm 9$ & $46 \pm 7$ & $90 \pm 1$ & $93 \pm 5$ & $51 \pm 5$ \\
\hline \multicolumn{10}{|c|}{ L. salivarius } \\
\hline 0 & - & - & - & - & - & - & - & - & - \\
\hline 24 & - & - & - & - & - & - & - & - & - \\
\hline 48 & - & $15 \pm 3$ & - & $14 \pm 2$ & $29 \pm 5$ & - & $4 \pm 1$ & $7 \pm 1$ & - \\
\hline 72 & $56 \pm 4$ & $75 \pm 6$ & - & $50 \pm 2$ & $66 \pm 5$ & $36 \pm 1$ & $41 \pm 9$ & $45 \pm 9$ & - \\
\hline 96 & $79 \pm 4$ & $90 \pm 8$ & - & $88 \pm 4$ & $84 \pm 7$ & $51 \pm 3$ & $53 \pm 10$ & $67 \pm 6$ & $20 \pm 4$ \\
\hline
\end{tabular}

${ }^{\star}$ Peptone-yeast-glucose.

$\dagger P Y G$ without glucose.

$\$ 10 \mathrm{mg}$ yeast extract $\mathrm{ml}^{-1}$.

-, No cells stained or no measurable biomass.

cell populations, their recovery from nutritional stress was different, suggesting that the response to other stresses might be similar.

The above hypothesis on the slow physiological response of biofilm cells is supported by the data generated by planktonic cultures incubated in buffer. As in the biofilm cultures, the number of metabolically active cells decreased dramatically to zero in both strains following $24 \mathrm{~h}$ in buffer (Figs 3b, 4f, 6b, 7f); however, the number of green undamaged cells did not change significantly, such that, at the beginning of the reactivation period with fresh PYG, the cultures were dominated (84-99\%) by undamaged cells that were metabolically inactive. However, unlike in the biofilms, the addition of fresh nutrients resulted in significant levels of CTC reduction at $2 \mathrm{~h}$, indicating an immediate increase in metabolism and rapid reactivation of the planktonic cultures (Figs $4 \mathrm{~g}, 7 \mathrm{~g}$ ). This observation highlights the difference in physiology between the biofilm and planktonic cultures, and also confirms the slower physiological response of biofilm cells (Mah \& O'Toole, 2001). The data produced by this study show that biofilm cells exhibit a slow physiological response, and unlike cells in planktonic culture, do not reactivate in short time periods even under optimal conditions.

S. anginosus and L. salivarius have different core physiological traits which may explain the differences observed in the time to reactivate from non-growth while forming biofilms. The main physiological characteristics of $S$. anginosus are the production of acetoin from glucose, and the hydrolysis of arginine (Ruoff, 1988). As arginine represents $8 \%$ of the amino acid content of PYG, it is possible that arginine is used as an alternative source to generate usable energy in the form of ATP during slow reactivation (Moat \& Foster, 1995). However, independent peptone mixtures in PYG did not reactivate $S$. anginosus. Interestingly, YE reactivated $S$. anginosus faster than PYG and PY (Table 1). In an additional experiment in which we measured $\mathrm{pH}$ in a culture of $S$. anginosus in YE during the exponential phase (data not shown), a $\mathrm{pH}$ drop from 7.5 to 5.5 was recorded, indicating that the $17.5 \%$ of non-defined carbohydrates in YE may be the main source for reactivation of $S$. anginosus. On the other hand, $L$. salivarius has a homofermentative metabolism as it produces large amounts of lactic acid from glucose, levulose, melibiose, trehalose, lactose, mannitol, etc. (Rogosa et al., 1953). However, the metabolic reactivation and biomass increase of L. salivarius with PY (Table 1) may indicate that the excess glucose in PYG was to some extent inhibitory to reactivation of $L$. salivarius cells from nutrient deprivation (Fig. 6a).

The methodology used in this study has allowed us to distinguish between membrane integrity and dehydrogenase and esterase activity of cells that had undergone nutrient deprivation and were reactivated by addition of fresh nutrients. The BacLight LIVE/DEAD assay system determined whether membrane damage had occurred during the period of nutrient deprivation. In both strains, neither the $24 \mathrm{~h}$ period of incubation in buffer nor reactivation with fresh medium significantly altered the proportion of green, undamaged cells. The CTC marker complemented the information given by the LIVE/DEAD 
staining by indicating the dehydrogenase activity of the cells under the same conditions. CTC scavenges electrons from microbial oxidation/reduction reactions and is intracellularly reduced to bright red formazan precipitates by the electron transport system (ETS) components or dehydrogenases in metabolically active micro-organisms. Kaprelyants \& Kell (1993) reported that in aerobic environments, CTC was reduced directly by ETS-associated dehydrogenase enzymes in M. luteus, and Lopez-Amoros et al. (1995) demonstrated that CTC could be reduced by $\mathrm{NAD}(\mathrm{P}) \mathrm{H}$ in fixed (formalin) E. coli. Smith \& McFeters (1997) further clarified that CTC reduction in aerobic $E$. coli $\mathrm{K}-12$ cultures is linked with dehydrogenase activity. In the present study, the relationship between growth and the ability to reduce CTC was optimal in the preliminary planktonic experiments with $S$. anginosus and L. salivarius, where exponential-phase growth was positively correlated with high levels of CTC reduction. This was also seen with the first reactivation sample at $2 \mathrm{~h}$, where CTC measurements increased in accordance with the increase in the bacterial population. CTC is commonly referred to as a marker of respiration; thus its effectiveness in oxygenlimited environments is thought to be doubtful. In the present study, we worked with CTC in biofilm and planktonic cultures under strict anaerobic conditions, and the results obtained were similar to preliminary experiments in aerobic cultures (data not shown). These data suggest that the reduction of CTC by bacteria is independent of the availability of oxygen, thus confirming the results from previous studies showing CTC reduction by a variety of anaerobes during all phases of growth (Bhupathiraju et al., 1999; Fukui \& Takii 1989; Walsh et al., 1995). Seemingly, intracellular enzymes (e.g. dehydrogenases) present during anaerobic processes (fermentation, nitrate reduction) are also capable of reducing CTC.

Since previous studies reported discrepancies with CTC and various cell-specific methods designed to distinguish active from inactive cells (Karner \& Fuhrman 1997; Nielsen et al., 2003), we included FDA as an extra marker of metabolic activity. FDA is hydrolysed in active bacteria by esterases, although other enzymes such as proteases and lipases can also hydrolyse FDA. The product of this enzymic conversion is fluorescein, which can be visualized within cells by fluorescence microscopy. FDA has previously been used to determine amounts of active bacteria in different environments including dental plaque (Brecx et al., 1990; Netuschil et al., 1998). In the present study, no major discrepancies were observed between the CTC and FDA results (Figs 3a, 6a). Normally, FDA yielded a slightly higher value of active cells than CTC (Table 1), and on some occasions, FDA-reactive cells were seen when no CTC activity was registered, e.g. at $48 \mathrm{~h}$ reactivation with PYG by S. anginosus (10\%) and L. salivarius ( $15 \%)$, and at $24 \mathrm{~h}$ reactivation with YE by $S$. anginosus (4\%). Similar differences between CTC and other vitality markers have been previously reported and indicated that CTC might detect cells which have greater metabolic activity compared to most cells that are scored as active (Longnecker et al., 2005; Sherr et al., 1999). In conclusion, the combination of LIVE/DEAD, CTC and FDA staining techniques to detect cells in a non-growing state and to evaluate their slow physiological response in biofilms appears to be satisfactory. However, other methods are obviously required for biofilm studies and might involve the use of more specific markers for other key cell-specific activities, such as fluorescence in situ hybridization (Nielsen et al., 2003).

The presence of bacteria in a state of non-growth could explain the survival of bacteria in persisting root canal infections, where micro-organisms must survive very low nutrient supplies, as well as exposure to calcium hydroxide when it is used as intracanal medication in root canal treatment (Chávez de Paz et al., 2003, 2007). In this line of argument, disease could be prevented not only by targeting 'pathogenic' organisms, but also by interfering in the reactivation of non-growing organisms. This work demonstrates that a phenotype giving rise to a slow recovery response is a characteristic of biofilm cells not shown by planktonic cells. The methodology used in this work could also be applied to test the physiological response of cells towards stresses such as antiseptics or antibiotics. Furthermore, studies on the factor(s) that promote recovery of the cellular metabolic activity are important to obtain information leading to a greater understanding of oral microbial ecology. The greater understanding of bacterial physiology and non-growing states has significance in relation to the control of oral diseases.

\section{ACKNOWLEDGEMENTS}

We gratefully acknowledge the excellent technical assistance of Ulrika Troedsson. The work was supported with research grants from the Knowledge Foundation (KK-stiftelsen, Biofilms - Research Center for Biointerfaces) and The Swedish Research Council (grant no. K2005-06X-12266-07A).

\section{REFERENCES}

Amy, P. S. \& Morita, R. Y. (1983). Starvation-survival patterns of sixteen freshly isolated open-ocean bacteria. Appl Environ Microbiol 45, 1109-1115.

Bhupathiraju, V. K., Hernandez, M., Landfear, D. \& Alvarez-Cohen, L. (1999). Application of a tetrazolium dye as an indicator of viability in anaerobic bacteria. J Microbiol Methods 37, 231-243.

Bowden, G. H. (1991). Which bacteria are cariogenic in humans? In Dental Caries, pp. 266-286. Edited by N. W. Johnson. Cambridge: Cambridge University Press.

Bowden, G. H. W. (1999). Controlled environment model for accumulation of biofilms of oral bacteria. Methods Enzymol 310, 216-224.

Bowden, G. H. \& Hamilton, I. R. (1989). Competition between Streptococcus mutans and Lactobacillus casei in mixed continuous culture. Oral Microbiol Immunol 4, 57-64.

Bowden, G. H. \& Hamilton, I. R. (1998). Survival of oral bacteria. Crit Rev Oral Biol Med 9, 54-85. 
Bowden, G. H. \& Li, Y. H. (1997). Nutritional influences on biofilm development. Adv Dent Res 11, 81-99.

Brecx, M., Netuschil, L., Reichert, B. \& Schereil, G. (1990). Efficacy of Listerine, Meridol and chlorhexidine mouthrinses on plaque, gingivitis and plaque bacteria vitality. J Clin Periodontol 17, 292-297.

Brown, M. R. \& Smith, A. W. (2001). Dormancy and persistence in chronic infection: role of the general stress response in resistance to chemotherapy. J Antimicrob Chemother 48, 141-142.

Carlsson, J. \& Johansson, T. (1973). Sugar and the production of bacteria in the human mouth. Caries Res 7, 273-282.

Chatterji, D. \& Ojha, A. K. (2001). Revisiting the stringent response, ppGpp and starvation signaling. Curr Opin Microbiol 4, 160-165.

Chávez de Paz, L. (2007). Redefining the persistent infection in root canals: possible role of biofilm communities. J Endod 33, 652-662.

Chávez de Paz, L. E., Dahlén, G., Molander, A., Möller, Å. \& Bergenholtz, G. (2003). Bacteria recovered from teeth with apical periodontitis after antimicrobial endodontic treatment. Int Endod J 36, 500-508.

Chávez de Paz, L. E., Molander, A. \& Dahlén, G. (2004). Grampositive rods prevailing in teeth with apical periodontitis undergoing root canal treatment. Int Endod J 37, 579-587.

Chávez de Paz, L., Svensäter, G., Dahlén, G. \& Bergenholtz, G. (2005). Streptococci from root canals in teeth with apical periodontitis receiving endodontic treatment. Oral Surg Oral Med Oral Pathol Oral Radiol Endod 100, 232-241.

Chávez de Paz, L. E., Bergenholtz, G., Dahlén, G. \& Svensäter, G. (2007). Response to alkaline stress by root canal bacteria in biofilms. Int Endod J 40, 344-355.

Davey, M. E. \& O'Toole, G. A. (2000). Microbial biofilms: from ecology to molecular genetics. Microbiol Mol Biol Rev 64, 847-867.

De Jong, M. H. \& Van der Hoeven, J. S. (1987). The growth of oral bacteria on saliva. J Dent Res 66, 498-505.

Foley, I., Marsh, P., Wellington, E. M., Smith, A. W. \& Brown, M. R. (1999). General stress response master regulator rpoS is expressed in human infection: a possible role in chronicity. $J$ Antimicrob Chemother 43, 164-165.

Frandsen, E. V., Pedrazzoli, V. \& Kilian, M. (1991). Ecology of viridians streptococci in the oral cavity and pharynx. Oral Microbiol Immunol 6, 129-133.

Fukui, M. \& Takii, S. (1989). Reduction of tetrazolium salts by sulfatereducing bacteria. FEMS Microbiol Ecol 62, 13-19.

Giard, J. C., Hartke, A., Flahaut, S., Boutibonnes, P. \& Auffray, Y. (1997). Glucose starvation response in Enterococcus faecalis JH2-2: survival and protein analysis. Res Microbiol 148, 27-35.

Gilbert, P., Maira-Litran, T., McBain, A. J., Rickard, A. H. \& Whyte, F. W. (2002). The physiology and collective recalcitrance of microbial biofilm communities. Adv Microb Physiol 46, 202-256.

Hall-Stoodley, L., Costerton, J. W. \& Stoodley, P. (2004). Bacterial biofilms: from the natural environment to infectious diseases. Nat Rev Microbiol 2, 95-108.

Holdeman, L. V., Cato, E. P. \& Moore, W. E. (1977). Anaerobe Laboratory Manual, 4th edn. Blacksburg, VA: Virginia Polytechnic Institute and State University.

Jenkins, D. E., Schultz, J. E. \& Matin, A. (1988). Starvation-induced cross protection against heat or $\mathrm{H}_{2} \mathrm{O}_{2}$ challenge in Escherichia coli. J Bacteriol 170, 3910-3914.

Kaprelyants, A. S. \& Kell, D. B. (1993). Dormancy in stationary-phase cultures of Micrococcus luteus: flow cytometric analysis of starvation and resuscitation. Appl Environ Microbiol 59, 3187-3196.
Karner, M. \& Fuhrman, J. A. (1997). Determination of active marine bacterioplankton: a comparison of universal 16S rRNA probes, autoradiography, and nucleoid staining. Appl Environ Microbiol 63, 1208-1213.

Kim, W. S., Park, J. H., Ren, J., Su, P. \& Dunn, N. W. (2001). Survival response and rearrangement of plasmid DNA of Lactococcus lactis during long-term starvation. Appl Environ Microbiol 67, 4594-4602.

Longnecker, K., Sherr, B. F. \& Sherr, E. B. (2005). Activity and phylogenetic diversity of bacterial cells with high and low nucleic acid content and electron transport system activity in an upwelling ecosystem. Appl Environ Microbiol 71, 7737-7749.

Lopez-Amoros, R., Comas, J. \& Vives-Rego, J. (1995). Flow cytometric assessment of Escherichia coli and Salmonella typhimurium starvation-survival in seawater using rhodamine 123, propidium iodide, and oxonol. Appl Environ Microbiol 61, 2521-2526.

Mah, T. F. \& O'Toole, G. A. (2001). Mechanisms of biofilm resistance to antimicrobial agents. Trends Microbiol 9, 34-39.

Marsh, P. D. (2005). Dental plaque: biological significance of a biofilm and community life-style. J Clin Periodontol 32 (Suppl. 6), 7-15.

Matin, A. (1990). Molecular analysis of the starvation stress in Escherichia coli. FEMS Microbiol Lett 74, 185-195.

Mechold, U. \& Malke, H. (1997). Characterization of the stringent and relaxed responses of Streptococcus equisimilis. J Bacteriol 179, 26582667.

Miethke, M., Westers, H., Blom, E. J., Kuipers, O. P. \& Marahiel, M. A. (2006). Iron starvation triggers the stringent response and induces amino acid biosynthesis for bacillibactin production in Bacillus subtilis. J Bacteriol 188, 8655-8657.

Moat, A. G. \& Foster, J. W. (1995). Amino acids, purines and pyrimidines. In Microbial Physiology, pp. 462-517. Edited by A. G. Moat \& J. W. Foster. New York: Wiley-Liss Inc.

Netuschil, L., Reich, E., Unteregger, E., Sculean, A. \& Brecx, M. (1998). A pilot study of confocal laser scanning microscopy for the assessment of undisturbed dental plaque vitality and topography. Arch Oral Biol 43, 277-285.

Nielsen, J. L., Aquino de Muro, M. \& Nielsen, P. H. (2003). Evaluation of the redox dye 5-cyano-2,3-tolyl-tetrazolium chloride for activity studies by simultaneous use of microautoradiography and fluorescence in situ hybridization. Appl Environ Microbiol 69, 641-643.

Oliver, J. D. (1995). The viable but non-culturable state in the human pathogen Vibrio vulnificus. FEMS Microbiol Lett 133, 203-208.

Rogosa, M., Wiseman, R. F., Mitchell, J. A., Disraely, M. N. \& Beaman, A. J. (1953). Species differentiation of oral lactobacilli from man including description of Lactobacillus salivarius nov spec and Lactobacillus cellobiosus nov spec. J Bacteriol 65, 681-699.

Ruoff, K. L. (1988). Streptococcus anginosus (“Streptococcus milleri”): the unrecognized pathogen. Clin Microbiol Rev 1, 102-108.

Sansone, C., Van Houte, J., Joshipura, K., Kent, R. \& Margolis, H. C. (1993). The association of mutans streptococci and non-mutans streptococci capable of acidogenesis at a low $\mathrm{pH}$ with dental caries on enamel and root surfaces. J Dent Res 72, 508-516.

Sherr, B. F., del Giorgio, P. \& Sherr, E. B. (1999). Estimating abundance and single-cell characteristics of respiring bacteria via the redox dye CTC. Aquat Microb Ecol 18, 117-131.

Smith, J. J. \& McFeters, G. A. (1997). Mechanisms of INT (2-(4iodophenyl)-3-(4-nitrophenyl)-5-phenyl tetrazolium chloride), and CTC (5-cyano-2,3-ditolyl tetrazolium chloride) reduction in Escherichia coli K-12. J Microbiol Methods 29, 161-175.

Socransky, S. S. \& Haffajee, A. D. (2002). Dental biofilms: difficult therapeutic targets. Periodontol 2000 28, 12-55. 
Steiner, K. \& Malke, H. (2000). Life in protein-rich environments: the relA-independent response of Streptococcus pyogenes to amino acid starvation. Mol Microbiol 38, 1004-1016.

Stevenson, L. H. (1977). A case for bacterial dormancy in aquatic systems. Microb Ecol 4, 127-133.

Van der Hoeven, J. S. \& Camp, P. J. (1991). Synergistic degradation of mucin by Streptococcus oralis and Streptococcus sanguis in mixed chemostat cultures. J Dent Res 70, 1041-1044.
Walsh, S., Lappin-Scott, H. M., Stockdale, H. \& Herbert, B. N. (1995). An assessment of the metabolic activity of starved and vegetative bacteria using two redox dyes. J Microbiol Methods 24, 1-9.

Watson, S. P., Clements, M. O. \& Foster, S. J. (1998). Characterization of the starvation-survival response of Staphylococcus aureus. J Bacteriol 180, 1750-1758.

Edited by: M. Kilian 